\title{
Heavy Metal Accumulation Affects the Structure of Microorganisms and Increases Abundance of Resistance Genes in Rare Earth Mining Areas
}

\section{Minjie Chen}

Inner Mongolia University of Science and Technology

Xiaoru Jiang

Inner Mongolia University of Science and Technology

\section{Zhansheng Mi}

Inner Mongolia University of Science and Technology

\section{Yafei Li}

Inner Mongolia University of Science and Technology

\section{Zhe Wang}

Inner Mongolia University of Science and Technology

\section{Xin Xu}

Inner Mongolia University of Science and Technology

\section{Chunli Zheng ( $\square$ nm_wx@163.com )}

Inner Mongolia University of Science and Technology https://orcid.org/0000-0002-3860-9634

\section{Research}

Keywords: Heavy-metal, Microbial structural diversity, Enzyme activities, Microbial function, Resistance gene

Posted Date: June 30th, 2021

DOI: https://doi.org/10.21203/rs.3.rs-639794/v1

License: (c) (i) This work is licensed under a Creative Commons Attribution 4.0 International License. Read Full License 


\section{Abstract \\ Background}

Environmental pollution from rare earth mining areas is of great concern, but the impact on microbial ecology and genomics has received little attention. In this study, the relationship between heavy metals and soil microbial community in the northern rare earth mining area was explored.

\section{Methods}

In order to study the detoxification mechanisms of heavy metals by microorganisms in this typical rare earth mining area, the study area was divided into three parts (mining area, residential area and control area). Analysis of microbial community diversity, structure and functional abundance using high-throughput sequencing techniques. Analysis of the effect of heavy metal pollution on the abundance of heavy metal resistance genes in soils of different regions using real-time fluorescence quantitative PCR.

\section{Results}

The results showed that the heavy metal pollution rules: mining area > residential area > control area. Under the condition of long-term heavy metal pollution, the original microbial community composition was changed, and the species richness and evenness of soil in mining areas were higher than that in residential areas. The high-throughput sequencing analysis showed that existed metal-resistant microbial communities such as Actinobacteria, Proteobacteria, Korarchaeota and so on under the stress of heavy metal. High concentrations of heavy metals can inhibit the activities of catalase and sucrase. According to Tax4Fun function prediction analysis, heavy metal accumulation increased the $A B C$ transporter protein in microbial function. The results of fluorescence quantification experiments also demonstrated that the abundance of heavy metal resistance genes, $c z c A, c z c B, c z c C$ and $c z c D$, encoding $A B C$ transporter proteins, increased with increasing heavy metal concentrations.

\section{Conclusions}

In conclusion, the accumulation of heavy metals not only changed the soil physicochemical properties and the microbial community structure, but also decreased soil enzyme activities and increased the abundance of resistance genes, which activated the detoxification mechanism of heavy metals. which provided a reference for future ecological remediation.

\section{Background}

The over-exploitation of rare earth elements has caused serious desertification and environmental pollution, and in China, ecological restoration of mining areas is receiving increasing attention(Wei et al., 2019 ; Wang et al., 2020). In recent years, with the increase of rare earth mining and smelting production, heavy metal pollution of soil in the surrounding areas has become a growing concern and a worldwide problem(Rodriguez et al., 2009; Frossard et al., 2018). So far, mining activities, especially the mining of metal ores, is a major source of soil heavy metal pollution(Huang et al., 2018). Due to different mining activities and habitat specificities, soil properties and heavy metal contents vary considerably over short spatial distances and elevation gradients (Zhao et al., 2019). Heavy metal pollutants caused by mining can be consumed by the human body through the food chain through soil, water, plants, 
etc., causing great harm to the human health (Liao and Xie 2007; Vinhal-Freitas et al., 2017). Soil contaminated with heavy metals causes changes in soil physicochemical properties and microbial activity, and microbial activity is more sensitive to heavy metals than animal or plant growth in the same soil, soil microbial biomass, soil enzyme activity and metabolic entropy are soil biological parameters(Liao and Xie, 2007), which are responsive to external conditions such as climate, human behavior and heavy metal pollution, and can reflect soil pollution status to some extent(Tang et al., 2019), It can be used as an effective index to evaluate the ecological impact of heavy metal pollution in soil (Ivshina et al., 2014).

Heavy metal contaminants have been shown to be harmful to soil microorganisms, and soil heavy metal contamination may lead to significant changes in microbial diversity, structure and activity(Filip, 2002; Nacke et al., 2014). Microorganisms make an important contribution to the maintenance of terrestrial ecosystems and their biodiversity because the enzymatic activity of soil microorganisms and soil microbial biomass control the cycling and storage of nutrients in the soil(Li et al., 2017). However, the presence of heavy metals in the mining process brings great pressure to microorganisms, which must survive in a heavy metal contaminated environment, thus having a greater impact on microbially mediated soil nutrient cycling(Khan et al., 2010). Both the concentration of heavy metals in the soil and their biological effectiveness influence the toxicity of heavy metals(Kenarova et al., 2014). Soil pH can influence the sorption of metals by substances in the soil, such as organic matter, by altering the surface charge and dissociability of heavy metal sorbents, which in turn affects the bioeffectiveness and toxicity of heavy metals to microorganisms(Bang and Hesterberg, 2004). Heavy metal contamination reduces soil microbial biomass, diversity and biochemical activity due to negative selection of microorganisms sensitive to heavy metal pollutants and inhibition of microbial metabolic activity(Azarbad et al., 2016; He et al., 2016; Yao et al., 2017), hence, low microbial biomass and slower soil organic matter decomposition activity in heavy metal contaminated soils due to low microbial biomass, functional diversity and metabolic efficiency of heavy metal tolerant bacteria in soil microbial communities(Mergeay, 2000). Heavy metals, soil and bacteria interact in a complex manner, and soil microbial communities play an important role in determining soil quality and regulating soil physicochemical properties(Guo et al., 2017); Therefore, soil microbial activity is often considered as a sensitive and effective indicator of mine ecosystems(Liao and Xie, 2007; Liu et al., 2016).

Soil enzyme activity is often considered as a sensitive biological index to evaluate soil quality(Spohn and Kuzyakov, 2014). Studies have shown that redox enzymes and hydrolytic enzymes can be mainly used to evaluate heavy metal pollution. In general, high concentrations of heavy metals could degrade soil cells, destroy soil microbial communities, and inhibit soil enzyme activity(Ciarkowska et al., 2014). Also, catalase is able to break down $\mathrm{H}_{2} \mathrm{O}_{2}$ and protect organisms from damage. In addition, catalase has been used as a bioindicator to detect the presence of various heavy metal contaminants(Xian et al., 2015; Hu et al., 2014). Sucrase activity reflects the ability of the soil to break down sucrose and free monosaccharides, which are the main source of energy for soil microorganisms (Frankenberger and Johanson, 1983). Thus, enzyme activity can be used to indicate improvements in the rehabilitation of soils after mining(Schimann et al., 2012). Enzymatic activities are also used for determining the effect of various pollutants including heavy metals on soil microbial quality(Shen et al., 2005; Khan et al., 2007). Studies have shown that heavy metals ( $\mathrm{Zn}, \mathrm{Cu}, \mathrm{Ni}, \mathrm{V}$ and $\mathrm{Cd}$ ) in soil would reduce the activities of soil urease, alkaline phosphatase and xylanase (Spohn and Kuzyakov, 2014). It was also found that soil microorganisms polluted by lead-zinc tailing dams reduced urease activity. Enzyme activity varies with the presence of heavy metals, and it depends on different soil properties, heavy metal types and concentrations. Therefore, the integration of multiple enzymes broadly representing microbial metabolism into a comprehensive index is necessary to assess both the toxicity levels of heavy metals in soil microcrops and the ecological impact of heavy metal contamination in soil systems. 
Microorganisms in soil contaminated by heavy metals have strong adaptability and viability. The emergence of heavy metal resistance genes in complex microbial communities under heavy metal stress reveals the biological processes and strategies necessary for the survival of microorganisms in extreme environments(Xavier et al., 2019; Thomas et al., 2020). Many bacteria have evolved genetic adaptations to adapt to their environment and acquire metal resistance, multiple genes such as $c a d B$, chrA, pbrA, MerA and NiCoT have reported systerms for bacterial resistance and detoxification, respectively for cadmium, chromium, lead, mercury and nickel, as well as in the involvement of transport of transition metals(Janssen et al., 2010; Das et al., 2016). In response to environmental pollution threatens the survival of microorganisms with various resistance mechanisms(Han et al., 2020), such as metal efflux pump mediated transport, metal produced by permeation barrier, the transformation of heavy metals by intracellular and extracellular enzymes and detoxification, this makes the microbes can by increasing the resistance mechanism of genes to expand their niche in heavy metal contaminated soil(Guo et al., 2018; Xi et al., 2021).

Due to mining activities, there are significant differences between heavy metal and physical and chemical properties in different regions(Kenarova et al., 2014), the microbial community structure will also be adjusted to adapt to different habitats. (Pérez-de-Mora et al., 2006; J Kozdroj, 2001). At present, the effects of tailing waste accumulation on the distribution of heavy metals and bacterial communities remain unclear. As a rare earth ore in the north, this region has a special habitat, it is of great significance to study the effects of rare earth mining on soil physical and chemical properties, heavy metals and soil bacterial communities. The present study aimed to (1) evaluate the effects of manganese $(\mathrm{Mn})$, copper( $\mathrm{Cu}$ ), lead $(\mathrm{Pb})$ etc. on soil enzyme activities, microbial function, community diversity in rare earth mining areas; (2) assess whether these microbial characteristics can be used as possible indicators of soil pollution by heavy metals and (3) analyze the influence of heavy metal pollution on the abundance of heavy metal resistance genes in soil in different regions.

\section{Material And Methods}

\subsection{Sample collection}

The sampling area for this study was in the northern rare earth mining area and its surrounding areas. According to the general layout of the rare earths, it was divided into three parts, namely the mining area(MA), the residential area(RA) and the control area(CA), as shown in the Fig. 1. Three $20 \times 20 \mathrm{~m}$ plots were established at each functional area and were considered true replicates in July 2019. There were 27 mining areas, 6 residential areas and 3 control areas. In detailed, at each sampling site, surface sediments $(0-20 \mathrm{~cm})$ were sampled in 3 points, the topsoil was collected from three random points by shovel at each plot and was placed into sterile centrifuge tube, immediately preserved with dry ice before being transported to the laboratory. Each sample was divided into three parts: one for DNA extraction and high-throughput sequencing of the soil microbes and stored in a refrigerator at $-80^{\circ} \mathrm{C}$, the other for chemical analysis stored at $4^{\circ} \mathrm{C}$ in the refrigerator for determination of soil enzyme activity, and the rest was air-dried for subsequent physical and chemical analysis.

\subsection{Physical and chemical analyses}

The pH was measured using a pH meter (PHS-3C, Shanghai INESA Instrument Co., Ltd., China), in 1:2.5 (soil/water) $\mathrm{H}_{2} \mathrm{O}$ suspensions after $1 \mathrm{~h}$ of shaking. The moisture content (MC) of the soil was determined by drying to a constant weight at $105^{\circ} \mathrm{C} \pm 2^{\circ} \mathrm{C}$ in a drying oven, then weighing. Cation exchange capacity (CEC) was determined by calcium acetate exchange method. Oxidation-reduction potential (ORP) was tested in accordance with the "Determination of soil redox potential Potentiometric method" (HJ 746-2015). The Electrical conductance (EC) of soil samples were determined using a conductivity meter (DDS-II A) [1:5.0 (w/v) soil/water ratio]. The soil organic matter (SOM)was 
investigated by the $\mathrm{K}_{2} \mathrm{Cr}_{2} \mathrm{O}_{7}$ colorimetric method(Jakobsen, 1998). The total nitrogen (TN) in the soil was determined by an SKD-1000 automatic azotometer (PEIOU, China). Total heavy metals ( $\mathrm{Mn}, \mathrm{Cu}, \mathrm{Zn}, \mathrm{Pb}, \mathrm{Cd}, \mathrm{Hg}$ ) were measured by ICP-AES(Tighe et al., 2006; Salvador et al., 2018) (PerkinElmer Optima 7300 DV, USA) after strong acid digestion (1:4 concentrated $\mathrm{HClO}_{4}$ and $\mathrm{HNO}_{3}(\mathrm{v} / \mathrm{v})$ ). Each sample had three replicates, and each tested sample was measured three times, in order to calculate the mean value.

\subsection{Typical enzymes activity experiments}

Soil enzyme activities were measured using the soil enzyme activity kit, which mainly measured five soil enzyme activities, namely, soil urease (UE), soil catalase (CAT), soil sucrose (SC), soil neutral phosphatase (NP) and soil alkaline phosphatase (ALP). Each index was measured for three repetitions in the same treatment(Gianfreda et al., 2005), and the enzyme activity was measured according to the instructions of the kit purchased (the kit was purchased from Nanjing Jiancheng Bioengineering Research Institute).

\subsection{DNA extraction, PCR, and high-throughput sequencing}

The 0.3-0.5 grams of soil sample was used for DNA extraction using the FastDNA® Spin Kit for soil (Magen, CHN). The V3-V4 region of the bacterial 16S rRNA gene was amplified(Dennis et al., 2013). The original sequencing sequence of the sample DNA fragment was obtained through llumina Miseq sequencing platform(Keegan et al., 2016), and a large number of reads were generated. In order to ensure the quality level of these reads and ensure subsequent analysis, sequencing quality control was required. First, stitching according to overlap, the sequenced joints and primers should be taken out. The low-quality data are then filtered to obtain the sequencing sequence available for subsequent analysis. OTU was screened with $97 \%$ similarity level, and each sample OTU was compared with the Silva database(Dickey et al., 2014). In order to obtain the species classification information corresponding to each OTU, RDP classifier was used for the taxonomic analysis of the OTU representative sequence.

\subsection{Quantitative analysis of resistance genes}

The normal PCR amplification of each functional gene was performed using the sample DNA as the template. Amplification products by agarose gel electrophoresis test, cut to strip, by DNA gel recovery kit back to collect pure, with cloning vector PGEM-T try agent box into the line of pure products of enzyme, and turned in sense the state cells Escherichia coli $\mathrm{DH} 5 \mathrm{a}$, blue white spot on the ampicillin flat screen, choose positive clone (white spot) propagation as microbial sequencing analysis, further cloning identification results. Plasmids was extracted from the cultured liquid, its concentration was determined, and the copy number was calculated. Gradient dilution was performed by a tenfold gradient. Fluorescence constant PCR amplification was performed using the different concentration standard as the mold plate, and the standard curve was drawn. Different functional groups were quantitatively amplified by fluorescence quantitative PCR. Quantitative PCR system: dye fluorescence quantitative reagent(SYBR premix Ex Taq) $10 \mu \mathrm{l}$, each of the upstream and downstream primers at $20 \mu \mathrm{mol} / \mathrm{L}$ was $0.5 \mu \mathrm{l}$, DNA template $1.0 \mu \mathrm{l}$, and the double steamed water was supplemented to $20 \mu \mathrm{l}(\mathrm{He}$ et al., 2016).

\subsection{Statistics and data analysis}

All data were analyzed using SPSS version 16.0 and Origin2019b. According to the annotation results of all sample species, the structure of phylum and genus level microbial community was analyzed. Using the principal component analysis (PCA) to the original environment data matrix for dimension reduction, correspondence analysis (CCA) was discussed environmental factors significantly influence microbial community structure(Magurran and Anne, 1988). The differences in the microbial diversity index and enzymatic activity were compared using Analysis of Variance (ANOVA, IBM SPSS 24.0).

\section{Results}




\subsection{Heavy metal accumulation changes soil physicochemical properties in rare earth mining areas}

The accumulation of heavy metals in rare earth mining areas has affected the physicochemical properties of the soil, the differences of soil physical and chemical properties in each sample point are shown in Table 1. The soil pH ranged from 7.93 to 8.77 all was alkaline. Soil moisture content ranges from 3.97-18.93\% Among all the sample points in the $\mathrm{MA}$, the EC value of soil samples ranged from $86.67 \mu \mathrm{s} / \mathrm{cm} \sim 4723.33 \mu \mathrm{s} / \mathrm{cm}$, the highest EC value was $5983.33 \mu \mathrm{s} / \mathrm{cm}$ in RA10, and the lowest EC value was $83.33 \mathrm{~s} / \mathrm{cm}$ in control area DZ12. The ORP ranged from $282.67 \mathrm{mv}$ to $331.67 \mathrm{mv}$, and there was no significant difference among the sampling points. The CEC of soil samples was $1.75 \sim 20.67$ $\mathrm{cmol} / \mathrm{kg}$. The minimum value was $1.75 \mathrm{cmol} / \mathrm{kg}$ at MA8 in the MA and the maximum value was $20.67 \mathrm{cmol} / \mathrm{kg}$ at DZ12 in the CA. The content of SOM was significantly different, ranging from $3.33 \%$ to $22.65 \%$, the content of SOM in the sampling point MA7 was the highest, reaching $22.65 \%$, and the content of organic matter in the comparison point DZ12 was the lowest, reaching $3.33 \%$. The TN content in the soil in the three regions ranged from the largest to the smallest as the $\mathrm{CA}>\mathrm{MA}>\mathrm{RA}$, with a range of $0.35-1.87 \mathrm{~g} / \mathrm{kg}$.

The heavy metal contents of soil was determined at all sampling sites (Fig. 2.). The metal concentrations of $\mathrm{Mn}$, Cu, $\mathrm{Zn}, \mathrm{Pb}, \mathrm{Cd}$ and $\mathrm{Hg}$ ranged from $532.80 \sim 14283.48,18.31 \sim 38.27,83.66 \sim 697.04,17.66 \sim 502.35,0.09 \sim 2.53$ and $0.04 \sim 0.85 \mathrm{mg} / \mathrm{kg}$, respectively. The average content of heavy metals is from high to low in soil: $\mathrm{Mn}>\mathrm{Zn}>\mathrm{Pb}>\mathrm{Cu}>\mathrm{Cd}$ $>\mathrm{Hg}$. The content of heavy metals in the MA was significantly higher than that in the RA and the CA, among which the content of $\mathrm{Mn}, \mathrm{Zn}, \mathrm{Pb}$ and $\mathrm{Cd}$ was the highest in the MA8 point of the MA, which was 26.8, 7.8, 28.44 and 28.1 times higher than that in the CA, respectively. Sample points MA3 and MA1 were the two most abundant points of $\mathrm{Cu}$, compared to the $\mathrm{CA}$, with maximum concentrations exceeding the by 2.1 times. With respect to $\mathrm{Hg}$, the content of MA9 was highest in the MA, followed by MA7, the value of the soil was reached by 21.0 times and 21.2 times of the CA, respectively.

\subsection{Heavy metals can affect soil enzyme activity}

Soil enzyme activity varies with soil environment and structural categories, but the degree of response of each enzyme was also important for different soil environments (Fig. 3). In this study, catalase activity (Fig. 3A) ranged from 24.42 to $61.15 \mu \mathrm{mol} \cdot \mathrm{g}^{-1} \mathrm{~d}^{-1}$, the highest value was $61.15 \mu \mathrm{mol} \cdot \mathrm{g}^{-1} \mathrm{~h}^{-1}$ at the reference point DZ12, and the lowest value was $24.42 \mu \mathrm{mol} \cdot \mathrm{g}^{-1} \mathrm{~h}^{-1}$ at the MA8 point in the MA. The content of Mn, Pb and $\mathrm{Cd}$ at this point was the highest, indicating that high concentration of heavy metals would inhibit catalase activity, and the highest value was about 2.5 times that of the lowest value. Sucrase activity(Fig. 3B) from high to low in turn was: CA, RA and MA, the highest in control point DZ12 value of $50.21 \mathrm{mg} \cdot \mathrm{g}^{-1} \mathrm{~d}^{-1}$, the lowest out now mine MA8 point of $30.53 \mathrm{mg} \cdot \mathrm{g}^{-1} \mathrm{~d}^{-1}$, that of Mn, Pb, Cd content was the highest, showed a high concentration of heavy metal concentrations were activated to restrain activity of invertase, high was about 1.65 times that of the lowest.

In this study, the highest value of urease activity (Fig. 3 C) occurred at the MA2 site at $5110.10 \mu \mathrm{g} \cdot \mathrm{g}^{-1} \mathrm{~d}^{-1}$, and the lowest value at the MA6 site at $1647.49 \mu \mathrm{g} \cdot \mathrm{g}^{-1} \mathrm{~d}^{-1}$, with the highest value being about 3.1 times of the lowest value. The range of alkaline phosphatase activity(Fig. 3D) was 818.92 9620.85 $\mu \mathrm{g} \cdot \mathrm{g}^{-1} \mathrm{~d}^{-1}$. The highest value was 9620.85 $\mu \mathrm{mol} \cdot \mathrm{g}^{-1} \mathrm{~d}^{-1}$ at the MA9 point in the MA, where the heavy metal content was low and the pollution was light. The lowest value was $818.92 \mu \mathrm{mol} \cdot \mathrm{g}^{-1} \mathrm{~d}^{-1}$ at the MA4 point in the MA, and the highest value was about 11.7 times of the lowest value. The neutral phosphatase activity (Fig. 3E) in the three regions from large to small was the MA $>$ RA $>C A$. The activity of alkaline phosphatase ranged from 3.35 to $9.49 \mu \mathrm{mol} \cdot \mathrm{g}^{-1} \mathrm{~d}^{-1}$, and the highest value was $9.77 \mu \mathrm{mol} \cdot \mathrm{g}^{-}$ ${ }^{1} \mathrm{~d}^{-1}$ at MA8 in the mining area, where the contents of $\mathrm{Mn}, \mathrm{Pb}$ and $\mathrm{Cd}$ were the highest. The lowest value was 3.35 $\mu \mathrm{mol} \cdot \mathrm{g}^{-1} \mathrm{~d}^{-1}$ at RA10 in the RA, and the highest value was about 2.9 times of the lowest value. 


\subsection{Correlation analysis between enzyme activity and environmental factors}

The correlation analysis between soil enzyme activity and environmental factors was shown in Fig. 4 Among the heavy metals in the soil of the study area, $\mathrm{Mn}, \mathrm{Zn}, \mathrm{Pb}$, and $\mathrm{Cd}$ had a great influence on the enzyme activity. Catalase activity and sucrase activity were negatively correlated with $\mathrm{Mn}, \mathrm{Zn}, \mathrm{Pb}$ and $\mathrm{Cd}$, with correlation coefficients between 0.68 and 0.8 , respectively. Catalase and sucrase activities were significantly positively correlated with soil pH, moisture content, Eh, CEC, clay and content. The sucrase activity was negatively correlated with total nitrogen and granule. Urease activity had no significant correlation with soil heavy metal content, but had positive correlation with water content, $\mathrm{pH}$ and sand. Neutral phosphatase was positively correlated with total nitrogen and powder content, but negatively correlated with sand content. Alkaline phosphatase was positively correlated with silt content in soil and negatively correlated with sand content.

\subsection{The richness and diversity of soil bacterial community changed in different regions}

The composition of soil microbial community was analyzed by non-metric multidimensional scale analysis (NMDS) as shown in Fig. 5. The microorganisms in the RA10, RA11 show a discrete state with other samples, indicating that the two sites were less similar to the species in the remaining mining areas. The distance between the control point and the sampling point in the mining area was relatively close, indicating that the soil sample taken from the control point and the sample taken from the mining area have a closer species composition, which was less similar to the samples taken from the RA.

In order to investigate the diversity and structure of the microbial communities, we used Illumina high-throughput sequencing technology to sequence the $16 \mathrm{~S}$ rRNA. The alpha diversity indices of the bacterial communities were shown in Table 2. From the perspective of community abundance, according to the analysis of the Chao index, the greater the Chao index, the greater the number of OTUs and the greater the number of sample species. In this study, the Chao index of the MA was greater than the RA and the CA, indicating that the MA has a higher species richness. Secondly, it can be seen from Shannon index and Simpson index that the diversity of microbial communities in MA was relatively high, which was quite different from RA. As far as the points in the MA were concerned, the heavy metals at points MA1, MA2, and MA3 in the MA were generally higher than those at points MA4, MA5, and MA6 in the MA. In terms of microbial diversity and abundance, the less polluted MA4, MA5, and MA6 points Shannon index and Simpson index are higher than MA1, MA2, MA3. This also proves that as the content of heavy metals increases, the microbial diversity in the soil will gradually decrease.

\subsection{Heavy metals can change the composition of soil bacterial community}

After quality filtering, high quality sequences of bacteria 16S rRNA V3 V4 were obtained from 12 soil samples in the mine area. Subsequently, a total of 266167 bacterial operational taxonomic units (OTUs) were assembled at a $97 \%$ confifidence interval. In total, we extracted 79 identified phyla from all soil samples (Fig. 6). At the phylum level, Actinobacteria, Proteobacteria, Chloroflexi and Thaumarchaeota were the most abundant phyla in mine soil. In addition, Actinobacteria were the most dominant phyla in the soils of MA and CA, the RA significantly enhanced the relative abundances of Proteobacteria compared to mine. Proteobacteria have become the most dominant group of bacteria in the RA of RA11 and RA12, The proportion of Actinomycetes was the largest in other mining areas and control points. In heavy metal highly polluted sediments, the abundance of Proteobacteria was relatively low. Secondly, 
some flora such as Korarchaeota, LCP_89, RsaHF231, etc. were not detected in RA and CA, but only in the MA, it might be due to that the long-term heavy metal pollution, specific resistant bacteria appeared, changed the original microbial community composition.

The genus level analysis of microorganisms in the mine area was shown in Fig. 7, Thiobacillus and Luteimonas had the highest abundance in RA11 of the RA, with an average abundance of $22.43 \%$ and $23.54 \%$, respectively, which were significantly different from the microbial communities in the MA and CA. The highest abundance of Solirubrobacter, Nocardia and Rubrobacter were found in the soil samples from the MA.

\subsection{Relationship between microbial abundance and environmental parameters}

Spearman order correlation was used to analyze correlations between environmental parameters and microbial abundance (Fig. 8). According to the analysis of the correlation between heavy metals and soil microbial community (phylum), it was found that Cyanobacteria and Chloroflexi were positively correlated with $\mathrm{Mn}(\mathrm{P}<0.05)$. Chloroflexi has a significantly positive relationship with $\mathrm{Zn}(\mathrm{P}<0.05)$, Zn was negatively correlated with Entotheonellaeota, thus inhibiting the growth of Entotheonelleota. $\mathrm{Pb}, \mathrm{Cd}$ were positively correlated with Cyanobacteria Patescibacteria, Chloroflexi $(\mathrm{P}<0.05)$, significantly negative correlated with Entotheonellaeota $(\mathrm{P}<0.05)$, inhibited the growth of the Entotheonellaeota phylum. There are two bacteria that are negatively associated with $\mathrm{Hg}$, including Unclassified and Armatimonadetes.

\subsection{Heavy metals can alter the function of microorganisms}

Functional contributions of bacteria in soil samples from different regions were predicted based on OTU levels through the Tax4Fun database. From Fig. 9, it can be seen that $A B C$ transport proteins and two-component regulatory systems accounted for the largest proportion of the predicted metabolic functions. The points MA7 and MA8, which were the most contaminated with $\mathrm{Pb}$ and $\mathrm{Cd}$ among all points, compared with the control points. It's worth noting that $\mathrm{ABC}$ transport proteins, a class of transporter protein, was higher in MA7 and MA8 than in the control site DZ12 in the heavily contaminated mine.

\subsection{Heavy metals can increase the resistance of resistance genes.}

Under the stress of heavy metals, the emergence of heavy metal resistance genes in complex microbial communities, microorganisms have a strong ability to adapt and survive in heavy metal contaminated soils. From the previous predictions of microbial metabolic functions, it was found that the $\mathrm{ABC}$ transporter proteins and two-component regulatory systems accounted for the largest proportion. Therefore, we selected $c z c A, c z c B, c z c C$, and $c z c D$ genes belonging to the $A B C$ transporter proteins to investigate the abundance of soil heavy metal resistance genes. The gene abundances of $C Z C A, C Z C B, C Z C C$ and $c z c D$ were shown in Fig. 10. By comparing the three points of MA7, MA8 and RA11, the sample sites MA7 and MA8 had higher gene abundance of $c z c A, c z c B, c z c C$ and $c z c D$ than RA11 which were high concentration of heavy metals by heavy metals $\mathrm{Zn}$ and $\mathrm{Cd}$, the gene abundances of $c z c A, c z c B, c z c C$ and $c z c D$ are higher than those of RA11. The gene abundance of $c z c A$ at the MA8 site was 0.4 times that of RA11 in residential areas, and the gene abundance of $c z c B$ at the most polluted MA8 site was 0.3 times of RA11 in residential areas. Gene abundance increases with increasing heavy metal concentrations, and through the outside to prevent $c z c A$ metal cation to enter the cell and was located in the outer membrane of regulon $c z c C$ relative expression of genes in the residential area were greater than the heavy metal pollution of mine, It was speculated that the studied area was a rare earth mining area, rare earth elements in the soil accumulation amount was larger, It interfered with the expression of $c z c A$ and $c z c C$ genes. The results showed that in the presence of a large number of $\mathrm{Zn}$ and $\mathrm{Cd}$ ions, the strains could adjust the expression of a large number of resistance genes in order to cope with the environmental changes. 


\section{Discussion}

\subsection{Significant differences in soil physicochemical properties and heavy metal distribution between regions}

Due to the frequent mining activities, heavy metal pollution of the mine soils is severe(Shu et al., 2003). Once these toxins enter agricultural soils, they could affect food production and security and pose a major threat to human health by entering the food chain (Guo et al., 2017). We assessed the ecological risks caused by these heavy metals, and investigated the structure and diversity of bacterial community under heavy metal pollution in this environment(Ma et al., 2020). Due to mining activity, the soil around rare earth mining area has been severely polluted not only with Mn and $\mathrm{Cu}$, but also with $\mathrm{Zn}, \mathrm{Pb}, \mathrm{Cd}$ and $\mathrm{Hg}$. The content of $\mathrm{Mn}, \mathrm{Pb}$ and $\mathrm{Cd}$ of heavy metals reached the highest in MA8 of the mining area, which might be caused by the low terrain of the sampling site. The main wind direction of rare earth mining area was the northwest wind, and the pollutants in the mining area migrate and accumulate along the wind direction. The pollution rules of the six heavy metals were all: MA > RA >CA. The heavy metal content in the MA was significantly higher than that in the residential area and the control area due to the influence of artificial mining activities, mining industry traffic and so on. In the accumulation of heavy metal elements in the soil, Mn, Zn content was the highest. The soil in the rare earth mining area was polluted by elements $\mathrm{Cd}, \mathrm{Pb}$ and $\mathrm{Mn}$ to different degrees, and showed a definite accumulation of pollution, which was consistent with the previous investigation on the pollution status of the mining area(Fu et al., 2016).

The correlations between heavy metals and some soil properties, such as CEC and SOM, were significant, which may due to the soil substances limiting the transfer of heavy metals. Organic matter content was an important part of soil, which provided nutrients and energy for microbial life activities(Aikpokpodion, 2010). The content of soil organic matter can reflect the level of soil fertility. The content of organic matter in the sampling point MA7 in the mining area was the highest, reaching $22.65 \%$. The high content of organic matter in the soil would affect the absorption of heavy metals in the soil. The high content of organic matter was conducive to the adsorption of heavy metals in soil. The content of organic matter in the control point DZ12 was the lowest of $3.33 \%$. This sampling point was less polluted by mining, less polluted in soil, has higher microbial activity in the soil, and more able to decompose organic matter, so the content of organic matter in the soil was relatively low. Soil structure, moisture and electrical conductivity also have essential effects on the migration of heavy metals in soil. Cation exchange capacity was the main source of soil buffering performance and the important basis for soil improvement and rational fertilization(Kelly et al., 1998; Wucheng, 2008). The smallest cation exchange capacity values for the soil samples were at sample site MA8, which is largely devoid of vegetation and heavily contaminated with heavy metals. The soil fertility at this site is poor. The maximum value was at sample point DZ12 in the control area, which was less affected by mining activities and less polluted by heavy metals. Therefore, the soil has a strong ability to retain fertilizer.

\subsection{Heavy metals changed the activity of enzymes in the soil}

Soil enzymes are considered as potential indicators of bacterial function and are closely related to soil biology and soil characteristics(García-Ruiz et al., 2008; Huang et al., 2019). In the soil of the study area, the heavy metals Cu, Zn, Cd and $\mathrm{Pb}$ had a great influence on the enzyme activity. Sucrase and catalase activities were lower in areas with high concentrations of heavy metals, while these two enzymes were significantly and negatively correlated with $\mathrm{Mn}, \mathrm{Zn}, \mathrm{Pb}$ and $\mathrm{Cd}$ in the soil, indicating that high concentrations of heavy metals inhibit enzyme activity (Borowik et al., 2014). Soil pollution levels and human activities will affect the migration and transformation of $\mathrm{Pb}$ in soil, thus affecting its bioavailability and biotoxicity. The activity of catalase and sucrase was similar, and will decrease with the increase of heavy metal concentration. These results were consistent with those reported by Belyaeva et al(Belyaeva et al., 2005). 
When the concentration of heavy metal exceeds a certain concentration, $\mathrm{Pb}, \mathrm{Cu}$ and $\mathrm{Zn}$ ions can directly bind to the enzyme or substrate in the soil, inhibiting the enzyme activity in the soil. In some sites, the content of organic matter in the soil was low, and the adsorption of gold ions was weak. $\mathrm{Pb}^{2+}$ was easy to bind to the enzyme free in the soil, and react with the active protein, such as to combine with mercapto to form metal sulfides, or to combine with the substrate to form complexes, thus to mask the binding site of the enzyme, and finally to inactivate or inhibit the enzyme activity(Dick, 1997; Roscoe et al., 2000).

\subsection{High concentration of heavy metals affected soil microbial community structure}

In order to study the richness, uniformity, diversity and sequencing coverage of each sample, diversity analysis was performed on the samples( Jennifer L et al., 2004). Long-term heavy metal pollution results in the change of soil microbial community structure, as well as the decrease of diversity and abundance(Xi et al., 2021). Soil

microorganisms have a weak response to low concentration of heavy metal pollution, and that exceeding the tolerance concentration of microorganisms will lead to the decrease of microbial population(Vig et al., 2004). In this study, the microbial abundance and multisampling of RA11 samples in the RA were both small, but the microbial abundance and diversity of MA4, MA5 and MA6 samples were relatively high. This may be due to the presence of certain resistant bacteria in the soil under the stress of long-term heavy metal pollution, which improved the microbial diversity(Choi and Journal, 2009). In addition, the stress of heavy metal Cd can lead to the disappearance of part of the flora and the emergence of specific resistant strains, which changes the composition of the original microbial community(Bartolomé et al., 2016). The heavy metals at MA1, MA2 and MA3 in the MA were generally higher than those at MA4, MA5 and MA6 in the MA. In terms of microbial diversity and abundance, the Shannon index and Simpson index of the lightly polluted MA4, MA5 and MA6 samples were all higher than those at MA1, MA2 and MA3. This also proves that the microbial diversity in soil decreases gradually with the increase of heavy metal content. Analysis at the microbial phylum level and genus level revealed that the abundance of the Actinobacteria was higher in the MA, while the abundance of the Proteobacteria was higher in the RA, and the corresponding abundance of the Solirubrobacter, Nocardia and Rubrobacter were higher in the MA than in the RA, and it can be concluded that heavy metals changed the microbial community structure in the area.Through the correlation analysis the negative effects of heavy metals on microbial community structure have been widely confirmed(Åkerblom et al., 2007; Zhang et al., 2015). Heavy metals may change the microbial community structure to a certain extent by destroying the cell structure, such as destroying chromosome replication and DNA synthesis, and then affecting nucleic acid metabolism(Zhang et al., 2015; Yan, 2020). Obviously, copper concentration is related to Methylococcales (phylum:

Proteobacteria;Class:Gammaproteobacteria), This may be because $\mathrm{Cu}^{2+}$ plays a key role in the nature and expression level of methane monooxygenase, and therefore plays a key role in the bacterial structure of methane-oxidizing bacteria(Semrau et al., 2010; Sara et al., 2016). Through the above understanding, aiming at the negative correlation of heavy metals to microorganisms and changed in microbial species in this study, it was proved that heavy metals have certain influence on the microbial community structure.

\subsection{Heavy metals promote certain functions of microorganisms}

Heavy metals have an important influence on microbial function(Liu et al., 2018; Singh et al., 2019). ABC transporter and two-component regulatory system accounted for the largest proportion in metabolic function prediction. MA7 and MA8 points with the heaviest $\mathrm{Pb}$ and $\mathrm{Cd}$ pollution among all the points were selected for comparison with the control points. It was found that MA7 and MA8 of ABC transporters were greater than the control point DZ12 in the heavily polluted mining area, indicating that under the stress of high concentration of heavy metal ions, $A B C$ transporters and the two-component regulatory system responded simultaneously and made corresponding adjustments to make a large number of $\mathrm{ABC}$ proteins expressed, which together eliminated the harmful substances such as heavy metals 
from the body(Liu et al., 2018). The two-component regulatory system enables bacteria to sense, respond to, and adapt to a wide range of environments, stressors, and growth strips. Therefore, when the concentration of heavy metal ions in the outside world increases, the proportion of the corresponding bicomponent system of microorganisms increases, thus further adapting to the complex environment(Wu et al., 2019).

\subsection{Heavy metals affected the expression of resistance gene}

Through quantitative analysis of heavy metal resistance genes, it was found that the abundance of resistance genes was higher in the sites with heavy metal pollution. In order to further study the influence of heavy metal resistance genes, the correlation analysis between heavy metal resistance genes and environmental factors showed that $c z c D$ gene was significantly correlated with $\mathrm{Zn}$, and significantly positively correlated with $\mathrm{Cu}$. Therefore, when the content of zinc and copper in the environment increased, $c z c D$ abundance, the regulatory gene of resistance gene in soil, was significantly promoted. The relative expression of $c z c D$ gene abundance was greater in the MA than in the RA, indicating that under the stress of heavy metal ions at high concentrations, $c z c D$ resistance gene was abundantly expressed to regulate $c z c A$ and $c z c B$, and the metal ions were transported through the metal transport mediated by the efflux pump. to the outside of the cell to complete the detoxification process of the soil. CzcD was involved in the regulation of the CZC system(Powell et al., 1994). It was a membrane-bound protein with at least four transmembraneheliums and was a subfamily member of the CDF protein family(Veglió et al., 1997). The role of $c z c D$ gene was mainly to regulate the heavy metal resistance of $c z c A$ and $c z c B($ Fisher, 1985). Therefore, $c z c D$ would increase under high concentration of $\mathrm{Zn}$ and $\mathrm{Cu}$ stress to resist environmental changes.

\section{Conclusions}

After a long period of mining activity, this rare earth mine has a special habitat and the environment around the mine has been heavily contaminated with heavy metals. The content of heavy metals in the soil around the mining area was increasing and the ecological risk will be higher and higher. It was found that high concentrations of heavy metals inhibited catalase and sucrase activity, but promote the activity of phosphatase. Under the condition of long-term heavy metal pollution, major microbial communities such as Actinobacteria and Proteobacteria have appeared in the MA, and only Korarchaeota, LCP_89, RsaHF231 and other resistant strains have been found in the MA. It was found that heavy metal accumulation could increase $A B C$ transporter proteins in microbial functions by high-throughput sequencing. $c z c A, c z c B, c z c C$, and $c z c D$ genes belonging to $A B C$ class of transporter proteins were selected for soil heavy metal resistance gene abundance survey, and it was found that $c z c A, c z c B, c z c C$, and $c z c D$ had higher gene abundance in heavy metal contaminated sites. Therefore, the method of analyzing the microbial community to evaluate the toxicity of heavy metals is very promising. However, we need to account for the direct impact of the soil properties on microorganisms before this method can be applied widely.

\section{Declarations}

Acknowledgments

We thank Research Center for Eco-Environmental Sciences for their assistance in sequencing and bioinformatics analysis.

Authors' contributions

Minjie Chen: Conceptualization, Methodology, Software, Writing- Original draft preparation, Writing - Review and Editing, Supervision; Xiaoru Jiang: Conceptualization, Methodology, Software, Investigation, Data curation, WritingOriginal draft preparation, Visualization; Zhansheng Mi: Data Curation, Software, Formal analysis, Visualization; Yafei 
Li: Supervision, Writing - Review and Editing; Zhe Wang: Supervision, Writing - Review and Editing; Xin Xu: Supervision, Writing - Review and Editing; Chunli Zheng: Conceptualization, Writing - Review and Editing, Supervision, Project administration, Funding acquisition.

Availability of data and materials

Data will be made available once the manuscript is accepted.

Declarations

Not applicable

Competing interests

The authors declare that they have no known competing financial interests or personal relationships that could have appeared to influence the work reported in this paper.

Funding

This research was supported by Inner Mongolia Science \& Technology Plan (2019 and 2020), National key research and development program (2018YFC1802904), the National Science Foundation of China (41561094 and 41867061), the Natural Science Foundation of Inner Mongolia Autonomous Region (2020MS02005), the Special Fund for the Transformation of Scientific and Technological Achievements in Inner Mongolia(2019CG062).

\section{References}

1. Aikpokpodion PE. Assessment of heavy metals pollution in fungicide treated cocoa plantations in ondo state, nigeria. Journal of Applied Biosciences. 2010;33:2037-46.

2. Azarbad H, Gestel CV, Niklińska M, Laskowski R, Röling W, Straalen NV. (2016). Resilience of soil microbial communities to metals and additional stressors: dna-based approaches for assessing "stress-on-stress" responses. International Journal of Molecular Sciences, 17(6).

3. Bang J, Hesterberg D. Dissolution of trace element contaminants from two coastal plain soils as affffected by $\mathrm{pH}$. J Environ Qual. 2004;33:891-901.

4. Bartolomé MC, et al., (2016). Morphological and Physiological Changes exhibited by a Cd-resistant Dictyosphaerium chlorelloides Strain and its Cadmium Removal Capacity. International Journal of Phytoremediation, 1171-1177.

5. Belyaeva ON, Haynes RJ, Birukova OA. Barley yield and soil microbial and enzyme activities as affected by contamination of two soils with lead, zinc or copper. Biology Fertility of Soils. 2005;41(2):85-94.

6. Borowik A, Wyszkowska J, Kucharski J, et al., (2014). Sensitivity of soil enzymes to excessive zinc concentrations. Journal of Elementology, 19(3/2014).

7. Choi, Jaeyoung. Adsorption, bioavailability, and toxicity of cadmium to soil microorganisms. Geomicrobiol J. 2009;26(4):248-55.

8. Chu D. (2018). Effects of heavy metals on soil microbial community. IOP Conference Series: Earth and Environmental Science 113.

9. Ciarkowska K, Ek-Podwika S, K., \& Wieczorek J. Enzyme activity as an indicator of soil-rehabilitation processes at a zinc and lead ore mining and processing area. J Environ Manage. 2014;132:250-6. 
10. Das S, et al. Genetic basis and importance of metal resistant genes in bacteria for bioremediation of contaminated environments with toxic metal pollutants. Appl Microbiol Biotechnol. 2016;100(7):2967-84.

11. Dennis KL, et al. Adenomatous polyps are driven by microbe-instigated focal inflammation and are controlled by IL-10-producing T cells. Can Res. 2013;73(19):5905-13.

12. Dick RP. (1997). Soil enzyme activities as integrative indicators of soil biological indicators for detecting changes in soil quality.

13. Dickey AM, et al. Estimating Bacterial Diversity in Scirtothrips dorsalis (Thysanoptera: Thripidae) via Next Generation Sequencing. Florida Entomologist. 2014;97(2):362.

14. Filip Z. International approach to assessing soil quality by ecologically-related biological parameters. Agriculture Ecosystems Environment. 2002;88(2):169-74.

15. Fisher NS. Accumulation of metals by marine picoplankton. Mar Biol. 1985;87(2):137-42.

16. Frankeberger WT, Johanson JB. Method of measuring invertase activity in soils. Plant Soil. 1983;74(3):301-11.

17. Frossard A, et al. Long- and short-term effects of mercury pollution on the soil microbiome. Soil Biol Biochem. 2018;120:191-9.

18. Fu Z, et al. Comparison of arsenic and antimony biogeochemical behavior in water, soil and tailings from Xikuangshan, China. Science of The Total Environment. 2016;539(JAN.1):97-104.

19. García-Ruiz R, et al. Suitability of enzyme activities for the monitoring of soil quality improvement in organic agricultural systems. Soil Biol Biochem. 2008;40(9):2137-45.

20. Gianfreda $L$, et al. Soil enzyme activities as affected by anthropogenic alterations: intensive agricultural practices and organic pollution. Sci Total Environ. 2005;341(1-3):265-79.

21. Guo $\mathrm{H}$, et al. Understanding the variation of microbial community in heavy metals contaminated soil using high throughput sequencing. Ecotoxicol Environ Saf. 2017;144:300-6.

22. Guo T, et al. Increased occurrence of heavy metals, antibiotics and resistance genes in surface soil after long-term application of manure. Sci Total Environ. 2018;635:995-1003.

23. Hongwei L, Mark, et al. (2016) Strategic tillage on a Grey Vertosol after fifteen years of no-till management had no short-term impact on soil properties and agronomic productivity. Geoderma, Geoderma, 267, 146-155.

24. $\mathrm{Han} \mathrm{H}$, et al. Heavy metal-immobilizing bacteria increase the biomass and reduce the $\mathrm{Cd}$ and $\mathrm{Pb}$ uptake by pakchoi (Brassica chinensis L.) in heavy metal-contaminated soil. Ecotoxicol Environ Saf. 2020;195:110375.

25. He Y, et al. Antibiotic and heavy-metal resistance of Vibrio parahaemolyticus isolated from fresh shrimps in Shanghai fish markets, China. Environ Sci Pollut Res. 2016;23(15):15033-40.

26. Hu XF, et al. Effects of mining wastewater discharges on heavy metal pollution and soil enzyme activity of the paddy fields. J Geochem Explor. 2014;147:139-50.

27. Huang L, et al. (2019). Soil bacterial community structure and extracellular enzyme activities under different land use types in a long-term reclaimed wetland. Journal of Soils and Sediments, 19(4).

28. Huang $Y$, et al. Heavy metal pollution and health risk assessment of agricultural soils in a typical peri-urban area in southeast China. J Environ Manage. 2018;207:159-68.

29. Ivshina IB, et al. Soil microbiocenosis as an indicator of stability of meadow communities in the environment polluted with heavy metals. Russian Journal of Ecology. 2014;45(2):83-9.

30. Jennifer L, Kirk., et al. Methods of studying soil microbial diversity. J Microbiol Methods. 2004;58(2):169-88.

31. Kozdroj J, E. J. Structural diversity of microbial communities in arable soils of a heavily. Appl Soil Ecol. 2001;17(1):31-42. 
32. Jakobsen BHJNH. (1998). K. H. Tan: Soil Sampling, Preparation, and Analysis.

33. Raton B, York LN, Singapore. The effect of soil management on olive yield and nutritional status of trees in rainfed orchards. Commun Soil Sci Plant Anal. 1970;35(9-10):1369-85.

34. Books in Soil, Plants, and the Environment, 45. Dekker, New York 1996. xx, 408 s., ill, 24 cm. USD 100. 93(3): 363373.

35. Janssen PJ, et al. The complete genome sequence of Cupriavidus metallidurans strain $\mathrm{CH} 34$, a master survivalist in harsh and anthropogenic environments. PLoS One. 2010;5(5):e10433.

36. Jarup L. Hazards of heavy metal contamination. Br Med Bull. 2003;68:167-82.

37. Kerblom S, Bth E, Bringmark L, et al. Experimentally induced effects of heavy metal on microbial activity and community structure of forest mor layers. Biology Fertility of Soils. 2007;44(1):79-91.

38. Keegan KP, et al. MG-RAST, a Metagenomics Service for Analysis of Microbial Community Structure and Function. Methods Mol Biol. 2016;1399:207-33.

39. Kelly JJ, et al. Effects of Heavy Metal Contamination and Remediation on Soil Microbial Communities in the Vicinity of a Zinc Smelter. J Environ Qual. 1998;27(3):65-71.

40. Kenarova A, et al. Community level physiological profiles of bacterial communities inhabiting uranium mining impacted sites. Ecotoxicology Environmental Safety. 2014;100:226-32.

41. Khan S, et al. Soil enzymatic activities and microbial community structure with different application rates of $\mathrm{Cd}$ and Pb. J Environ Sci. 2007;19(7):834-40.

42. Khan $\mathrm{S}$, et al. Effects of $\mathrm{Cd}$ and $\mathrm{Pb}$ on soil microbial community structure and activities. Environ Sci Pollut Res. 2010;17(2):288-96.

43. Kjeldsen P, et al. Present and Long-Term Composition of MSW Landfill Leachate: A Review. Critical Reviews in Environmental Science Technology. 2002;32(4):297-336.

44. Li X, et al. Response of soil microbial communities and microbial interactions to long-term heavy metal contamination. Environ Pollut. 2017;231:908-17.

45. Liao M, Xie XM. Effect of heavy metals on substrate utilization pattern, biomass, and activity of microbial communities in a reclaimed mining wasteland of red soil area. Ecotoxicology Environmental Safety. 2007;66(2):217-23.

46. Liu J, et al. Microbial community structure and function in sediments from e-waste contaminated rivers at Guiyu area of China. Environ Pollut. 2018;235(apr.):171-9.

47. Ma $\mathrm{Y}$, et al. Assessment of heavy metal pollution and the effect on bacterial community in acidic and neutral soils. Ecol Ind. 2020;117(1):106626.

48. Magurran AE. Ecological Diversity and Its Measurement. Princeton University Pre; 1988.

49. Mergeay M. Bacteria adapted to industrial biotopes: metal-resistant Ralstonia. In: " in Responses BS, eds Storz G, editors. and R. Hengge-Aronis. Washington DC: ASM Press; 2000. pp. 403-14.

50. Nacke H, et al. Land Use Type Significantly Affects Microbial Gene Transcription in Soil. Microb Ecol. 2014;67(4):919-30.

51. Pérez-de-Mora A, et al. Microbial community structure and function in a soil contaminated by heavy metals: effects of plant growth and different amendments. Soil Biol Biochem. 2006;38(2):327-41.

52. Powell KA, et al. (1994). The Genus Aspergillus II Interactions of Fungi with Toxic Metals. 10.1007/978-1-48990981-7\$4Chapter 28): 361-374.

53. Rodriguez L, et al. Heavy metal distribution and chemical speciation in tailings and soils around a $\mathrm{Pb}-\mathrm{Zn}$ mine in Spain. J Environ Manage. 2009;90(2):1106-16.

Page 14/ 28 
54. Roscoe R, et al. Urease activity and its relation to soil organic matter, microbial biomass nitrogen and urea-nitrogen assimilation by maize in a Brazilian Oxisol under no-tillage and tillage systems. Biology Fertility of Soils. 2000;32(1):52-9.

55. Salvador RMV, et al. Tropidurus torquatus (Squamata: Tropiduridae) as a bioindicator of heavy metal (aluminum and zinc) pollution in Vila Velha, Brazil. Environ Sci Pollut Res. 2018;25(2):1210-9.

56. Sara, et al. Evaluation of the influence of methane and copper concentration and methane mass transport on the community structure and biodegradation kinetics of methanotrophic cultures. J Environ Manage. 2016;171:1120.

57. Schimann $\mathrm{H}$, et al. Microbial bioindicators of soil functioning after disturbance: The case of gold mining in tropical rainforests of French Guiana. Ecol Ind. 2012;20:34-41.

58. Semrau JD, et al. (2010). Methanotrophs and copper. Fems Microbiology Reviews, (4), 496-531.

59. Shen $\mathrm{G}$, et al. Interaction of polycyclic aromatic hydrocarbons and heavy metals on soil enzyme. Chemosphere. 2005;61(8):1175-82.

60. Shu WS, et al. "Restoration of lead and zinc mine tailings in South China. Acta Ecol Sin. 2003;23(8):1629-39.

61. Singh JP, et al. Soil microbial response to metal contamination in a vegetated and urban brownfield. J Environ Manage. 2019;244(AUG.15):313-9.

62. Spohn M, Kuzyakov Y. Spatial and temporal dynamics of hotspots of enzyme activity in soil as affected by living and dead roots-a soil zymography analysis. Plant Soil. 2014;379(1-2):67-77.

63. Tang $\mathrm{J}$, et al. Diagnosis of soil contamination using microbiological indices: A review on heavy metal pollution. $J$ Environ Manage. 2019;242:121-30.

64. Thomas JC, et al. Co-occurrence of antibiotic, biocide, and heavy metal resistance genes in bacteria from metal and radionuclide contaminated soils at the Savannah River Site. Microb Biotechnol. 2020;13(4):1179-200.

65. Tighe M, et al. (2006). "Tan, K.H., 2005. Soil Sampling, Preparation and Analysis. Taylor \& Francis Group.

66. Veglió F, et al. Biosorption of toxic metals: an equilibrium study using free cells of Arthrobacter sp. Process Biochem. 1997;32(2):99-105.

67. Vig K, et al. Bioavailability and toxicity of cadmium to microorganisms and their activities in soil: a review. Adv Environ Res. 2004;8(1):121-35.

68. Vinhal-Freitas IC, et al. Soil textural class plays a major role in evaluating the effects of land use on soil quality indicators. Ecol Ind. 2017;74:182-90.

69. Wang L, et al. (2020). Response mechanism of microbial community to the environmental stress caused by the different mercury concentration in soils. Ecotoxicology and Environmental Safety, 188(Jan.), 109906.1-109906.7.

70. Wei Z, et al. The effects of phytoremediation on soil bacterial communities in an abandoned mine site of rare earth elements. Science of The Total Environment. 2019;670:950-60.

71. Wu H, et al. Bacterial community composition and function shift with the aggravation of water quality in a heavily polluted river. J Environ Manage. 2019;237(MAY 1):433-41.

72. Wu cheng. Effect of pyrolysis temperature on cationic exchange capacity of black carbon and adsorption capacity of lead and cadmium. Journal of Agro-Environment Science. 2008;026(003):1169-72.

73. Xavier JC, et al. Evaluation of the microbial diversity and heavy metal resistance genes of a microbial community on contaminated environment. Appl Geochem. 2019;105:1-6.

74. Xi B, et al. (2021). Insights into the effects of heavy metal pressure driven by long-term treated wastewater irrigation on bacterial communities and nitrogen-transforming genes along vertical soil profiles. Journal of Hazardous Materials, 403.

Page 15/28 
75. Xian Y, et al. Quantitative assessment on soil enzyme activities of heavy metal contaminated soils with various soil properties. Chemosphere. 2015;139(NOV.):604-8.

76. Yan C, Wang F, Geng H, et al. (2020). Integrating high-throughput sequencing and metagenome analysis to reveal the characteristic and resistance mechanism of microbial community in metal contaminated sediments. Science of the Total Environment." 707(Mar.10): 136116.136111-136116.136111.

77. Yao A, et al. Effects of an iron-silicon material, a synthetic zeolite and an alkaline clay on vegetable uptake of As and $\mathrm{Cd}$ from a polluted agricultural soil and proposed remediation mechanisms. Environ Geochem Health. 2017;39(2):353-67.

78. Zhang W, et al. High throughput sequencing analysis of the joint effects of BDE209-Pb on soil bacterial community structure. J Hazard Mater. 2015;301:1-7.

79. Zhao X, et al. Study on the influence of soil microbial community on the long-term heavy metal pollution of different land use types and depth layers in mine. Ecotoxicol Environ Saf. 2019;170:218-26.

\section{Tables}

Table 1 Soil properties at each site. Abbreviations: TN, total nitrogen; ORP, oxidation-reduction potential; EC, lectrical conductance; $\mathrm{CEC}$,cation exchange capacity; SOM, soil organic matter. Data are reported as means \pm standard deviations $(n=3)$. Levels that are not linked by the same letter differ significantly. 


\begin{tabular}{|c|c|c|c|c|c|c|c|}
\hline Sample & $\mathrm{pH}$ & $\mathrm{EC}(\mu \mathrm{s} / \mathrm{cm})$ & $\begin{array}{l}\text { Moisture } \\
\text { (\%) }\end{array}$ & $\mathrm{ORP}(\mathrm{mV})$ & CEC & $\begin{array}{l}\text { SOM } \\
(\%)\end{array}$ & $\mathrm{TN} \rrbracket \mathrm{g} / \mathrm{kg} \rrbracket$ \\
\hline MA1 & $8.74 \pm 0.01 a b$ & $346.67 \pm 4.68 \mathrm{~g}$ & $\begin{array}{l}13.32 \% \\
\pm 0.90 \mathrm{c}\end{array}$ & $331.33 \pm 4.68 a$ & $2.42 \pm 0.10 \mathrm{i}$ & $\begin{array}{l}13.45 \% \\
\pm 0.14 \mathrm{bc}\end{array}$ & $0.43 \pm 0.02 i$ \\
\hline MA2 & $8.71 \pm 0.09 b c$ & $113.33 \pm 3.33 j$ & $\begin{array}{l}5.62 \% \\
\pm 2.13 \mathrm{e}\end{array}$ & $328.33 \pm 2.34 b$ & $7.01 \pm 0.23 c$ & $\begin{array}{l}10.01 \% \\
\pm 0.25 \mathrm{bc}\end{array}$ & $0.63 \pm 0.02 \mathrm{~g}$ \\
\hline MA3 & $8.15 \pm 0.03 e f$ & $273.33 \pm 7.62 \mathrm{~h}$ & $\begin{array}{l}4.61 \% \\
\pm 0.97 \mathrm{~g}\end{array}$ & $295.67 \pm 3.28 \mathrm{~g}$ & $3.92 \pm 0.16 \mathrm{~g}$ & $\begin{array}{l}8.63 \% \\
\pm 0.38 \mathrm{bc}\end{array}$ & $0.73 \pm 0.04 \mathrm{ef}$ \\
\hline MA4 & $8.20 \pm 0.03 e$ & $230.00 \pm 3.78 \mathrm{i}$ & $\begin{array}{l}6.48 \% \\
\pm 0.96 \mathrm{e}\end{array}$ & $298.33 \pm 4.15 f$ & $3.84 \pm 0.34 h$ & $\begin{array}{l}6.07 \% \\
\pm 0.68 \mathrm{c}\end{array}$ & $0.35 \pm 0.01 j$ \\
\hline MA5 & $7.93 \pm 0.01 i$ & $1236.67 \pm 9.76 c$ & $\begin{array}{l}4.00 \% \\
\pm 0.96 \mathrm{~h}\end{array}$ & $282.67 \pm 5.18 \mathrm{k}$ & $4.86 \pm 0.20 f$ & $\begin{array}{l}9.31 \% \\
\pm 0.62 \mathrm{bc}\end{array}$ & $1.45 \pm 0.06 c$ \\
\hline MA6 & $8.10 \pm 0.03 \mathrm{fg}$ & $753.33 \pm 5.34 \mathrm{e}$ & $\begin{array}{l}5.37 \% \\
\pm 0.77 f\end{array}$ & $293.00 \pm 7.13 \mathrm{~h}$ & $2.19 \pm 0.18 \mathrm{k}$ & $\begin{array}{l}6.76 \% \\
\pm 0.81 \mathrm{c}\end{array}$ & $0.72 \pm 0.09 f$ \\
\hline MA7 & $8.77 \pm 0.01 a$ & $4723.33 \pm 6.21 b$ & $\begin{array}{l}18.93 \% \\
\pm 3.11 a\end{array}$ & $331.67 \pm 1.66 a$ & $5.43 \pm 0.45 e$ & $\begin{array}{l}22.65 \% \\
\pm 0.28 a\end{array}$ & $0.95 \pm 0.05 d$ \\
\hline MA8 & $8.00 \pm 0.05 h$ & $360.00 \pm 5.90 f$ & $\begin{array}{l}3.97 \% \\
\pm 1.68 \mathrm{~h}\end{array}$ & $287.00 \pm 2.62 j$ & $1.75 \pm 0.20$ I & $\begin{array}{l}6.23 \% \\
\pm 0.32 \mathrm{c}\end{array}$ & $0.74 \pm 0.01 \mathrm{e}$ \\
\hline MA9 & $8.66 \pm 0.03 c$ & $86.67 \pm 7.32 \mathrm{k}$ & $\begin{array}{l}15.36 \% \\
\pm 0.70 \mathrm{~b}\end{array}$ & $324.33 \pm 4.68 c$ & $6.54 \pm 0.24 d$ & $\begin{array}{l}11.32 \% \\
\pm 0.41 \mathrm{bc}\end{array}$ & $1.79 \pm 0.06 b$ \\
\hline RA10 & $8.28 \pm 0.02 e$ & $5983.33 \pm 8.98 a$ & $\begin{array}{l}9.41 \% \\
\pm 0.38 \mathrm{~d}\end{array}$ & $304.00 \pm 6.12 \mathrm{e}$ & $9.13 \pm 0.45 b$ & $\begin{array}{l}12.30 \% \\
\pm 0.65 \mathrm{bc}\end{array}$ & $0.51 \pm 0.01 \mathrm{~h}$ \\
\hline RA11 & $8.07 \pm 0.01 \mathrm{~g}$ & $843.33 \pm 13.47 d$ & $\begin{array}{l}13.73 \% \\
\pm 0.65 \mathrm{c}\end{array}$ & $291.00 \pm 3.64 i$ & $2.30 \pm 0.68 \mathrm{j}$ & $\begin{array}{l}16.11 \% \\
\pm 0.08 \mathrm{ab}\end{array}$ & $0.62 \pm 0.04 \mathrm{~g}$ \\
\hline DZ12 & $8.51 \pm 0.02 d$ & $83.33 \pm 4.901$ & $\begin{array}{l}6.09 \% \\
\pm 0.56 \mathrm{e}\end{array}$ & $317.00 \pm 4.69 d$ & $20.67 \pm 0.38 a$ & $\begin{array}{l}3.33 \% \\
\pm 0.06 a\end{array}$ & $1.87 \pm 0.05 a$ \\
\hline
\end{tabular}

Due to technical limitations, Table 2 is only available as a download in the Supplemental Files section.

\section{Figures}




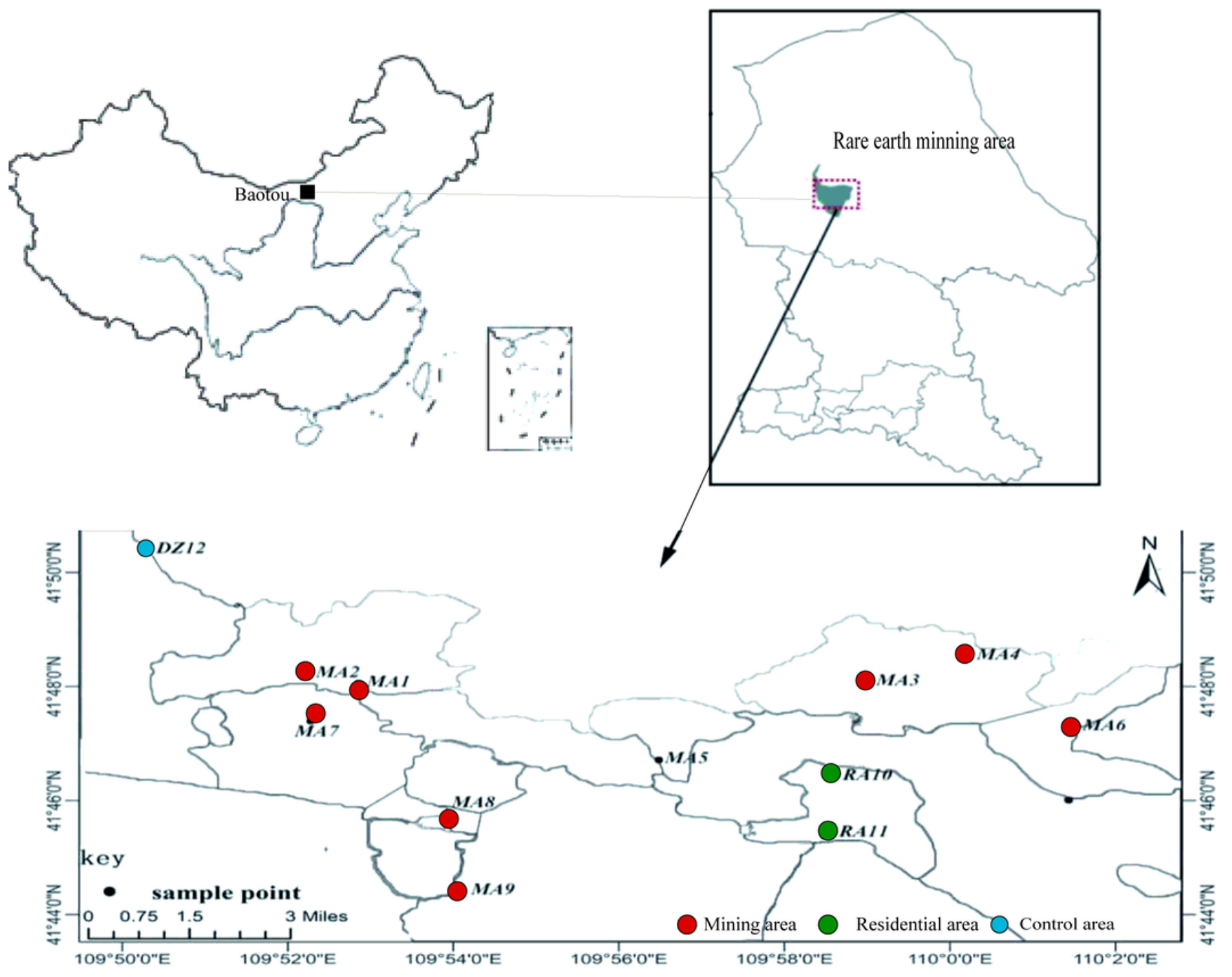

Figure 1

Map of the rare earth mining area and location of the sampling point. 

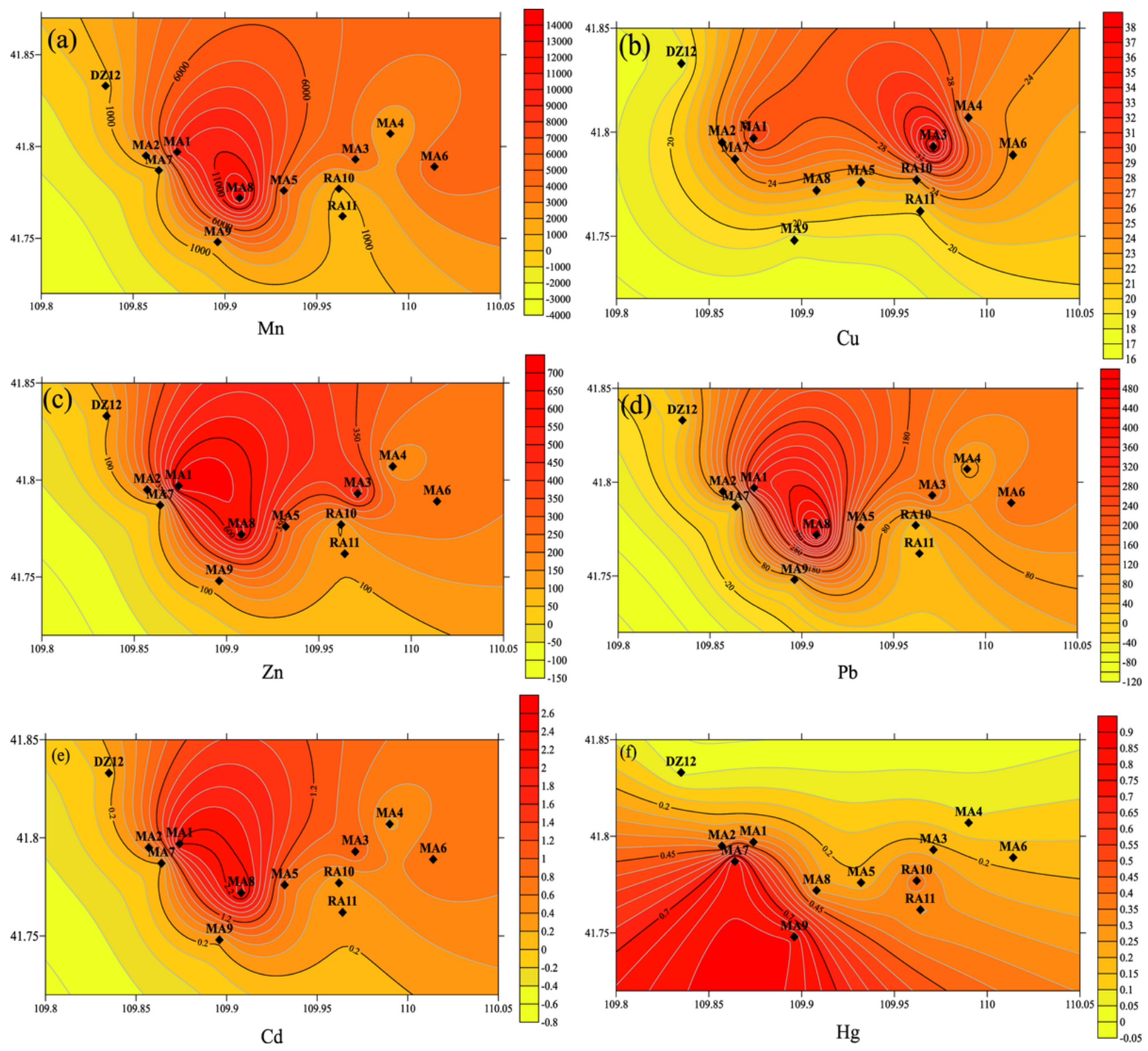

Figure 2

Change of heavy metal concentration in soil around rare earth tailings $(\mathrm{Mg} / \mathrm{kg})$ 

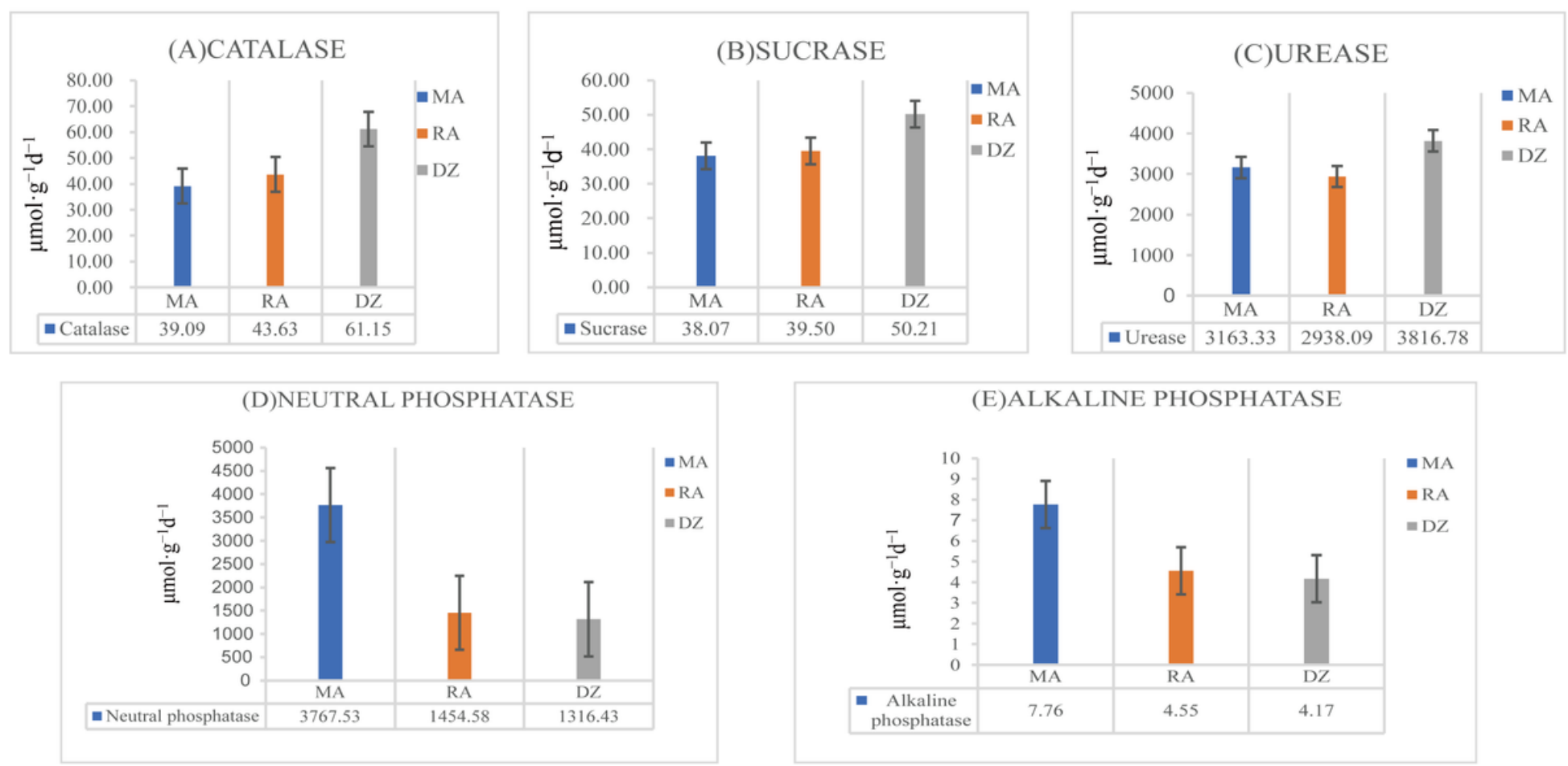

\section{Figure 3}

Soil enzyme activity under heavy metal-contaminated soil. 


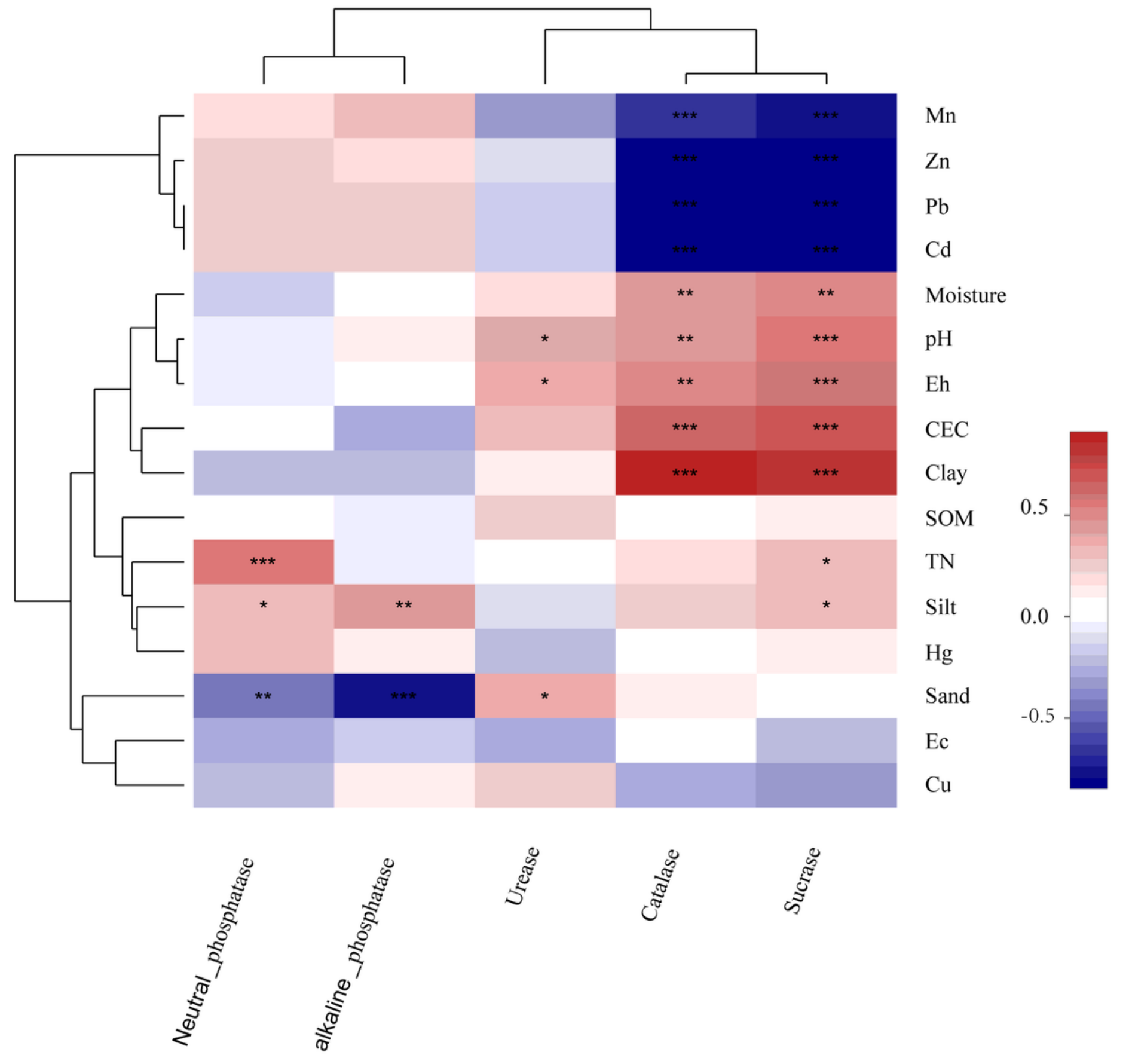

\section{Figure 4}

Heat map of the correlation between soil enzyme activities and properties in soil samples based on Pearson's correlation coefficients. Strong positive correlation (red); weak correlation (red); strong negative correlation (blue); *significant correlation $(P<0.05)$; ** significant correlation $(P<0.01)$. 
stess 0.073

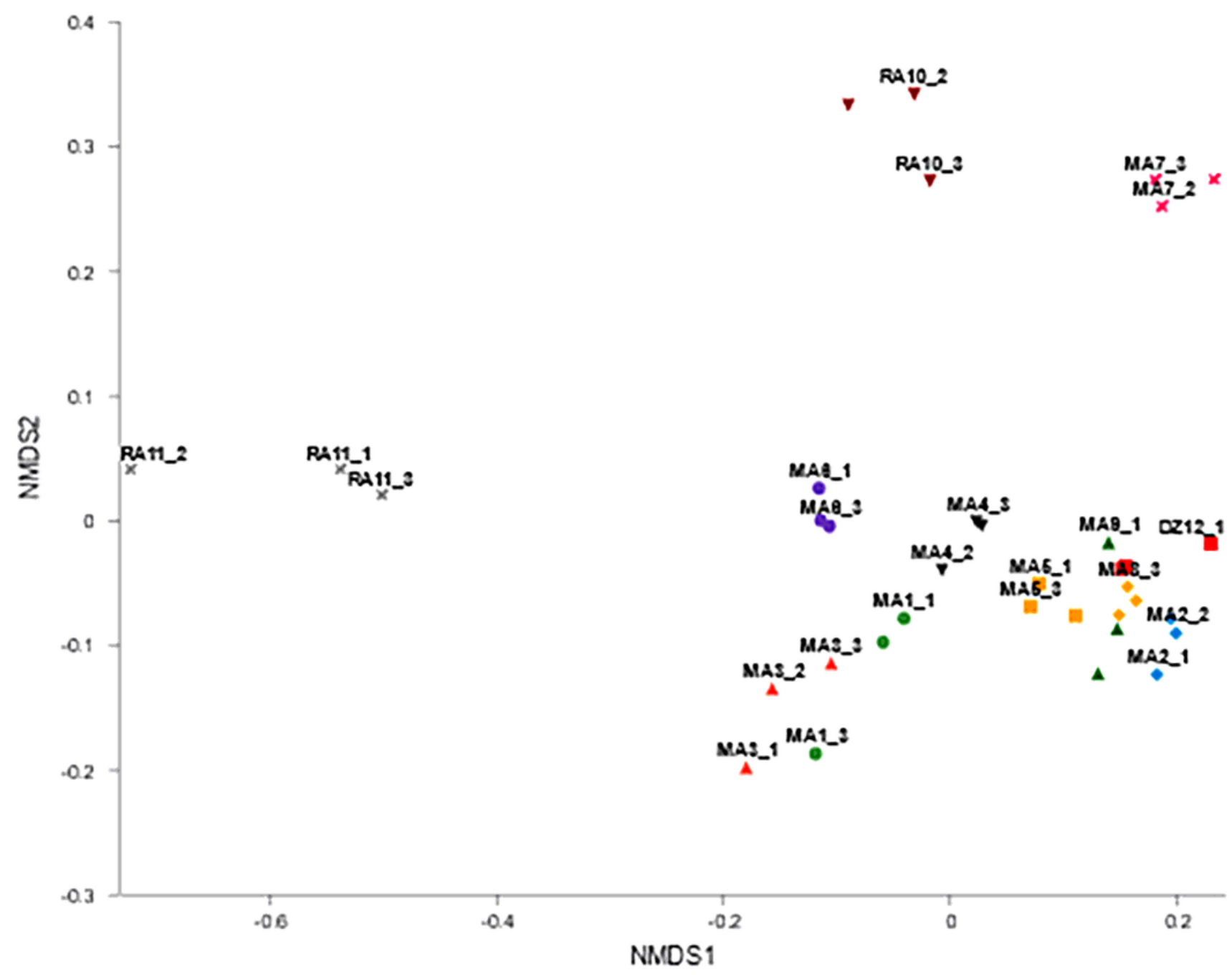

Figure 5

Non-metric multidimensional scale analysis of soil samples. 


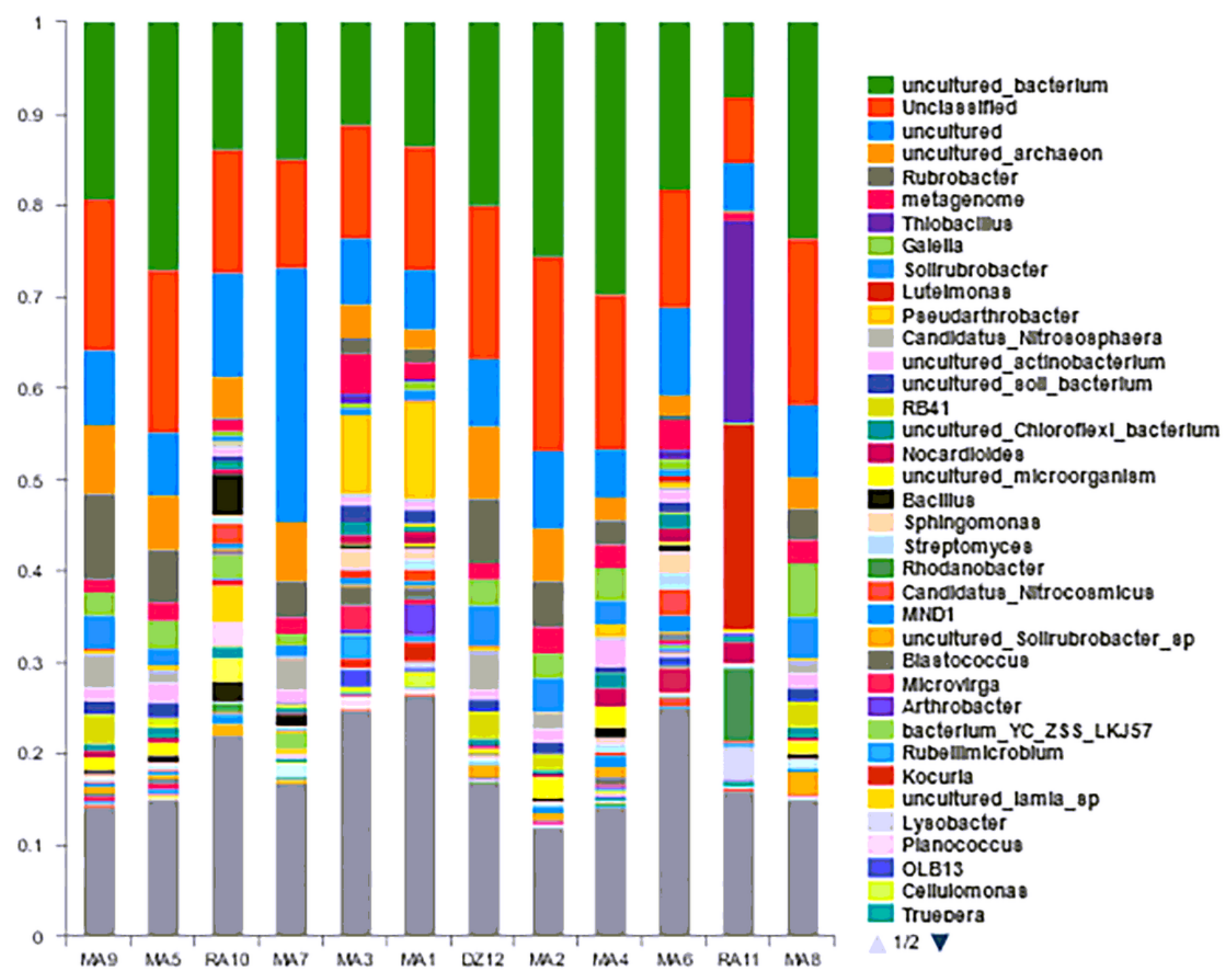

Figure 6

The relative abundance distribution bar chart of bacterial species (phylum level). 

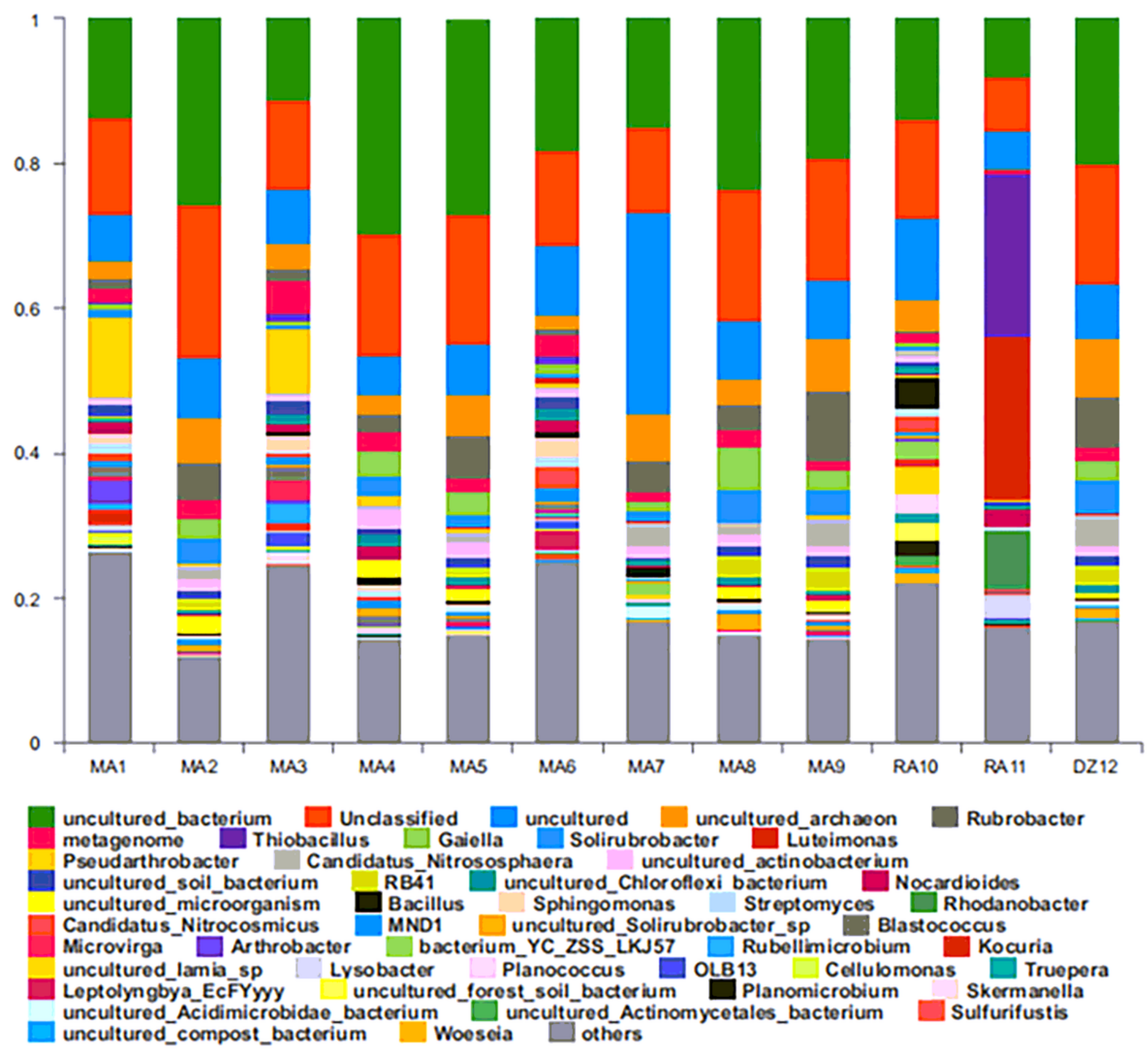

Figure 7

The relative abundance distribution bar chart of bacterial species (genus level). 


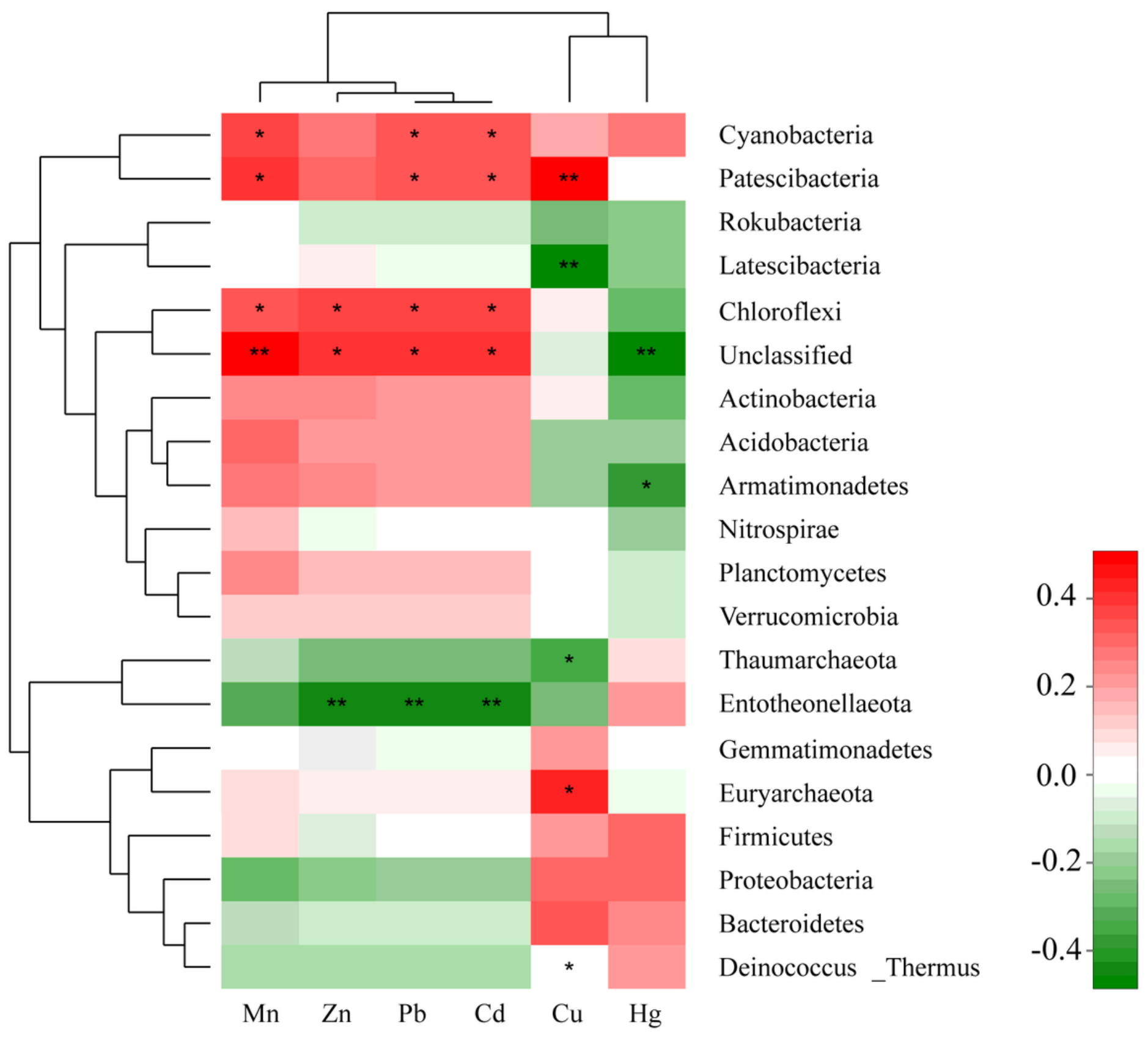

Figure 8

Spearman rank correlation to study the environmental factors and microbial species richess. 

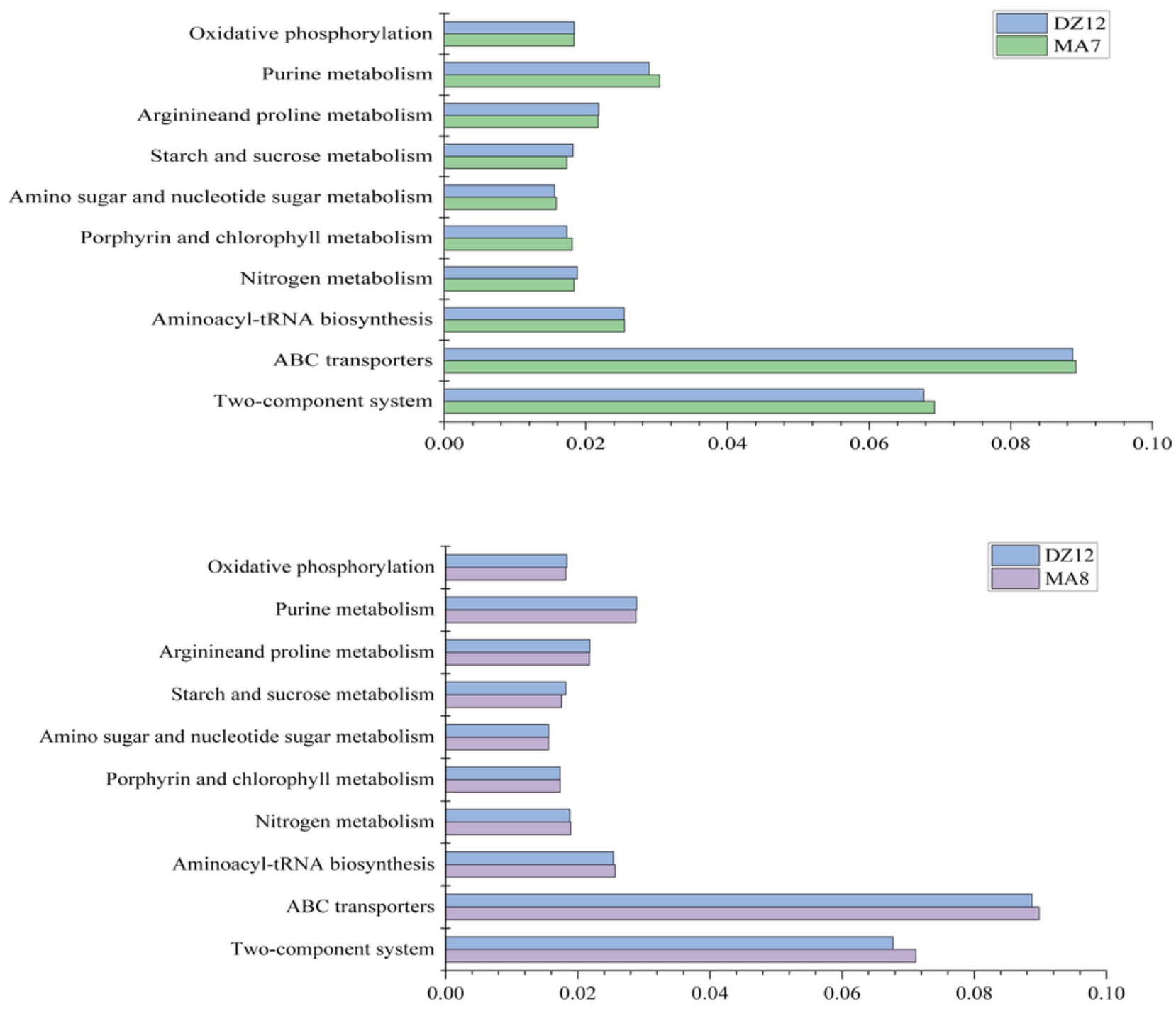

\section{Figure 9}

Functional prediction of microbial community in mining area. 

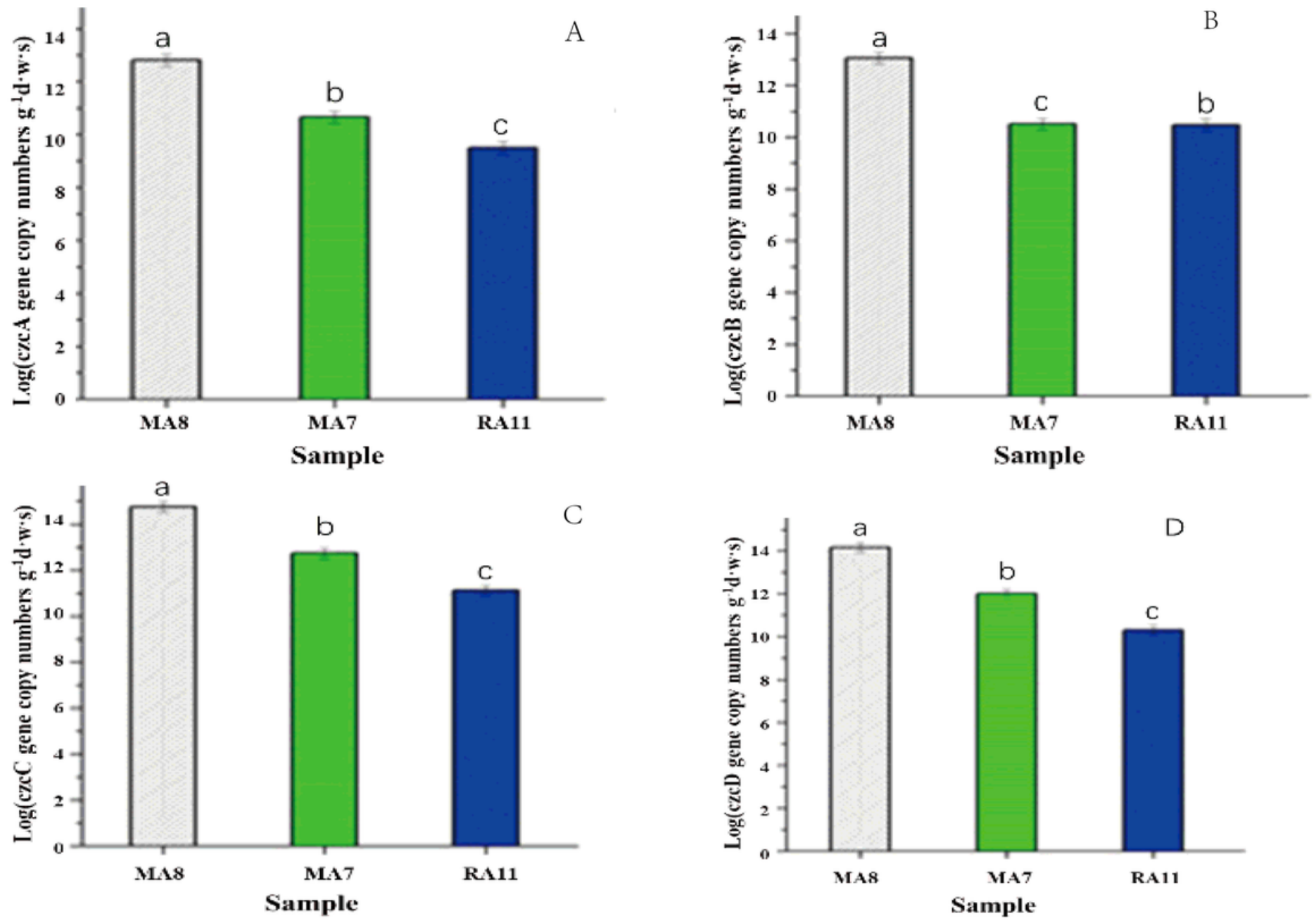

Figure 10

Abundance of heavy metal resistance genes. 


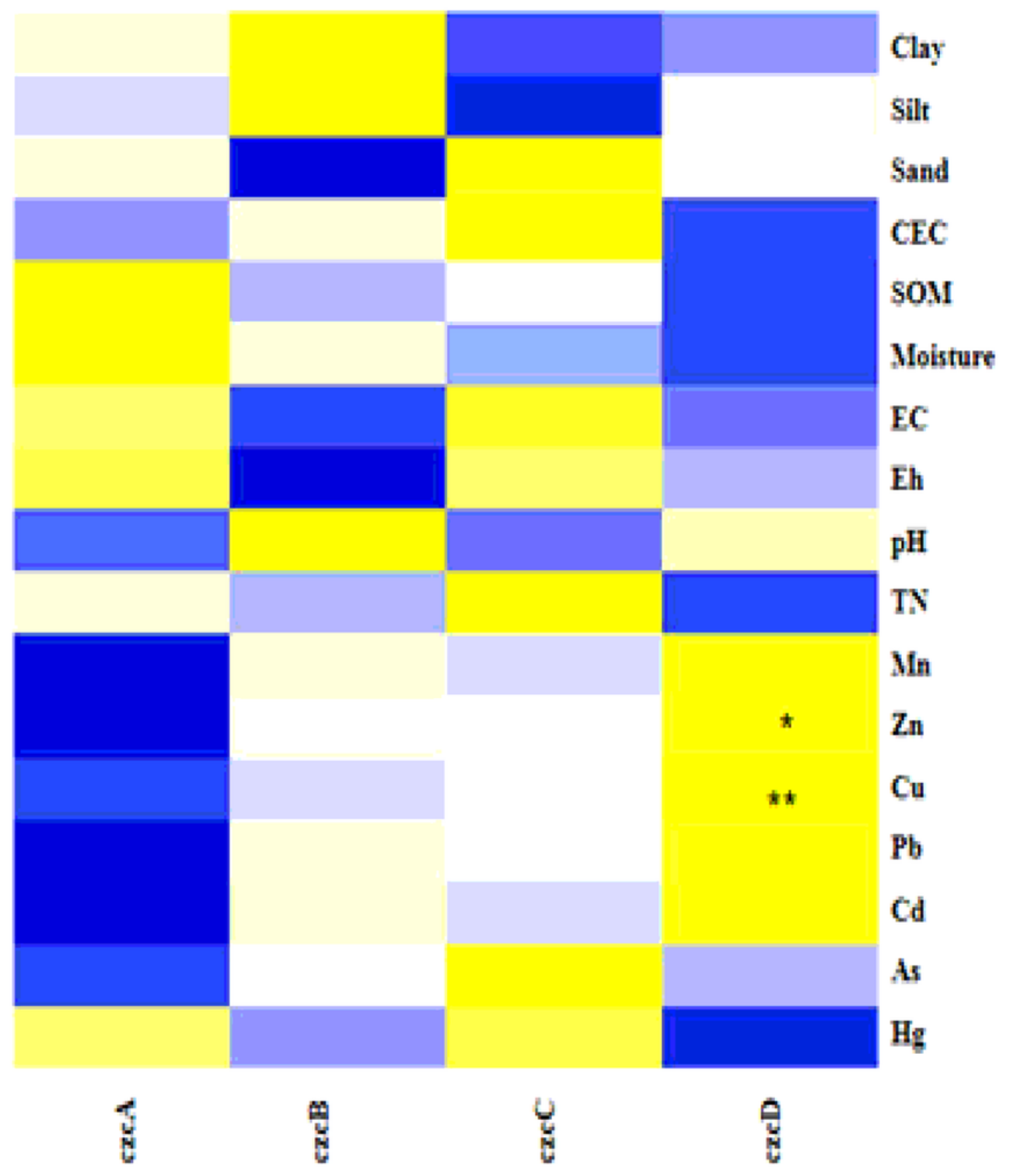

Figure 11

Correlation analysis between environmental factors and heavy metal resistance genes.

\section{Supplementary Files}

This is a list of supplementary files associated with this preprint. Click to download.

- Table2Bacterialalphadiversityindex.docx

- GraphicalAbsaract.png 